\title{
Fine Particulate Matter and Heavy Metals Pollution Status in Ambient Air of Some Selected Industrial Sites in Northern Nigeria
}

\section{Tyoyima John Ayua*, Aondongu Alexander Tyovenda, Terver Sombo, Emmanuel Vezua Tikyaa, Tertsea Igbawua}

Department of Physics, Federal University of Agriculture, Makurdi, Nigeria

Email: *ayuajohn2@gmail.com

How to cite this paper: Ayua, T. J., Tyovenda, A. A., Sombo, T., Tikyaa, E. V., \& Igbawua, T. (2020). Fine Particulate Matter and Heavy Metals Pollution Status in Ambient Air of Some Selected Industrial Sites in Northern Nigeria. Journal of Geoscience and Environment Protection, 8, 1-13. https://doi.org/10.4236/gep.2020.88001

Received: July 6, 2020

Accepted: August 7, 2020

Published: August 10, 2020

Copyright $\odot 2020$ by author(s) and Scientific Research Publishing Inc. This work is licensed under the Creative Commons Attribution International License (CC BY 4.0).

http://creativecommons.org/licenses/by/4.0/

(c) (i) Open Access

\begin{abstract}
Fine particulate matter and eight heavy metals $(\mathrm{Ni}, \mathrm{Co}, \mathrm{Cu}, \mathrm{Pb}, \mathrm{Cd}, \mathrm{Cr}, \mathrm{Mn}$, and $\mathrm{Zn}$ ) concentrations were determined in air samples collected from three industrial sites in northern Nigeria using a Handheld Portable Particle Counter for $\mathrm{PM}_{2.5}$ and $\mathrm{PM}_{10}$ with model number CW-HAT 200 and a High Volume Respirable Dust Sampler (APM $460 \mathrm{NL}$ ) in conjunction with an Atomic Absorption Spectrophotometer (Serial No. AA0904M046) Flame Test. The results of the fine particulates ranged from $11.0-46.0 \mu \mathrm{g} \cdot \mathrm{m}^{-3}$ for $\mathrm{PM}_{2.5}$ and 22.0 - $88 \mu \mathrm{g} \cdot \mathrm{m}^{-3}$ for $\mathrm{PM}_{10}$ across all the industrial sites investigated. Most of these results exceeded the WHO permissible levels of $25.0 \mu \mathrm{g} \cdot \mathrm{m}^{-3}$ and $50.0 \mu \mathrm{g} \cdot \mathrm{m}^{-3}$ for $\mathrm{PM}_{2.5}$ and $\mathrm{PM}_{10}$ and thus pose threats to people living and working close to these sites. The concentration of the heavy metals studied were found to be within $\mathrm{WHO} / \mathrm{EU}$ set standards except for the concentrations of $\mathrm{Ni}, \mathrm{Pb}$, and $\mathrm{Cd}$ that exceeded the set standard by $\mathrm{WHO} / \mathrm{EU}$ with toxicity potential $>1$ in the Terytex industry, Kano and Grand Cereals, Jos. Strong positive correlations were found between the fine particulates concentrations and heavy metals in all the studied sites suggesting that common anthropogenic sources contributed to the fine particulates and heavy metals recorded from the industrial areas. We suggested the installation of electrostatic precipitators to combat fine particulates emission from the stack and also recommended a proper legislative framework by the government to regulate and control industrial fugitive emissions to protect human health.
\end{abstract}

\section{Keywords}

Fine Particulate Matter, Heavy Metals, Toxicity Potential, Human Health, Correlation Analysis 


\section{Introduction}

Air pollution research has gained a lot of prominences worldwide in recent times, because of the increased level of anthropogenic activities and climatic change arising from the quest for industrialization in all cities of the world. It is one of the major causes of deterioration in human health conditions as the breathing of safe air is important just as safe water or food (Akolkar et al., 2015). Particulates matter is known to be one of the most threatening atmospheric pollutants on human health conditions, together with sulfur dioxide, nitrogen dioxide, and ozone (WHO, 2016). Fine Particulate $\left(\mathrm{PM}_{2.5}\right.$ and $\left.\mathrm{PM}_{10}\right)$ being of special concern. These particulates are emitted from a variety of sources, mainly from traffic and industrial production, as well as by natural sources like desert dust outbreaks, forest fires and dust resuspension by wind (Karagulian et al., 2015). Exposures to fine particulates are linked to decreased lung function and increased respiratory symptoms such as airways irritation, coughing, or difficulty breathing and possibly worsen COVID-19 symptoms (Carretero-Peña et al., 2019). Therefore, monitoring fine particulates pollution and controlling their emission levels in the surrounding air have become one of the major concerns of environmental protection agencies and public health protection organizations.

It has been reported by many researchers that anthropogenic activities are a major cause of heavy metals and fine particulates matter contaminants in the air (Kasassi et al., 2008; Zhang et al., 2010). Industrial operations in developed and developing countries are known to contribute greatly to anthropogenic air pollution with particulate matter and the gaseous pollutants been released mostly at levels that constitute environmental nuisance (Tyovenda et al., 2016; Hadlocon et al., 2015). Ambient air pollution by heavy metals is a universal problem because most of the metals are inextinguishable and can pose serious risks to human health, plants, animals, ecosystems, or other media (Khan et al., 2008; Zeireini et al., 2005; Shinggu et al., 2010; Abah et al., 2020).

Lopez et al. (2005) reported that anthropogenic activities releasing fine particulates and heavy metals into the air contribute about $4 \%-8 \%$ of deaths annually in the world that has linked to air pollution. Constituents of air pollution may be organic, inorganic, or a combination of both with heavy metals contents which continuously contaminates the ambient air for many decades, even after they are no longer being emitted into the atmosphere. The effects of this pollution not only degrade the quality of air, water, and food crops but are also detrimental to human health and animals (Dong et al., 2011; Anietie \& Labunmi, 2015; Abah et al., 2020). Unlike other pollutants, heavy metals can go unnoticed while building in air or soil at concentrations that are toxic to living things (Taghipour et al., 2013; Melaku et al., 2008). Toxicity signs for each heavy metal vary; for instance, $\mathrm{Cu}, \mathrm{As}, \mathrm{Pb}, \mathrm{Hg}, \mathrm{Al}$ poisoning, and $\mathrm{Zn}$ are known to cause gastrointestinal disorders, stomatitis, tremor, diarrhea, ataxia, paralysis, hemoglobinuria, vomiting and convulsion, pneumonia, and depression (Singh et al., 2010). 
Lin et al. (2016) reported that excessive intake of $\mathrm{Pb}$ into the human body can damage the nervous, skeletal, endocrine, enzymatic, circulatory, and immune systems. Cadmium intake can cause chronic effects such as lung cancer, kidney dysfunction, prostatic proliferative lesions, pulmonary adenocarcinomas, prostatic proliferative lesions, and bone fractures (Brevik et al., 2015).

In recent years, Northern Nigerian major cities have witnessed rapid population growth of humans, and increased rate of industrial activities with the resultant increase in fine particulate levels and heavy metals degrading the air quality.

Unfortunately, these cities and industries have no capacity and facilities to combat air pollution from the source thus, all industrial emissions are deposited into the air leaving nature to take its cause. These may result to enhance levels of particulate matter and heavy metals loading in the immediate vicinity and the resulting consequences on the biological system. Despite this, no comprehensive data has been published on the fine particulate and heavy metals pollution status of the immediate industrial vicinities in northern Nigeria. Thus, this study focuses on assessing the current pollution status of environmentally concerned fine particulate $\left(\mathrm{PM}_{2.5810}\right)$ and heavy metals in the ambient air within the vicinity of some selected northern Nigeria industries to gauge the values with set regulatory standards. It is hoped that the study will provide baseline data for continuous monitoring of the impact of fine particulate and the heavy metals content of the immediate industrial environment and hence, useful in recommending precautionary measures that could limit the exposure of the people living and working close to the industrial area to particulate and metal pollutants.

\section{Materials and Methods}

\subsection{Sampling Tool and Procedures}

The sampling tools used were HAT $200 \mathrm{PM}_{2.5-10}$ detector, and a High Volume Respirable Dust Sampler (APM $460 \mathrm{NL}$ ) model. The former is a digital meter that displayed the concentrations of $\mathrm{PM}_{2.5}$ and $\mathrm{PM}_{10}$ simultaneously on the screen while, the later consists of an inlet pipe with an inbuilt flow rate meter and a filter adaptor assembly which is connected by a cyclone to the sampling pump, to which airborne particulates was collected on a rectangular Whatman glass fiber filter papers (GF/A) 20.32 by 25.40 centimeters. The gas flow rate meter has a rating of about $0.90-1.20 \mathrm{~m}^{3} /$ minutes of air samples. The sampling tools were placed at an elevation of 150.0 centimeters above the ground level to reflect the average breathing height of a human.

In preparation to commence sampling, all the filter papers' initial weights were recorded after drying them in desiccators at a temperature range of $22^{\circ} \mathrm{C}$ $25^{\circ} \mathrm{C}$. After exposing the pre-weighed filter papers for about eight hours, they were dried again in desiccators and re-weighed to determine the final weight laden with the particulates.

The concentration of the fine particulates in the air was read directly on the 
screen and also determined from the relation presented in Equation (1) using filter papers. Equation (1) was, however, only applicable to $\mathrm{PM}_{10}$ and was used only in August 2019, when heavy metals analysis was to be carried out on the filter papers.

$$
\operatorname{Con}\left(\mu \mathrm{g} \cdot \mathrm{m}^{-3}\right)=\frac{(\text { Final }- \text { Initial }) \text { weight of filter paper }}{\text { Volume of air Sampled }(V)} \times 10^{6}
$$

where $V=\phi \times t, \phi=$ mean flow rate readings in $\mathrm{m}^{3} /$ minutes and $t$ is sampled time in minutes, $10^{6}$ is the conversion factor from grams to micrograms (Tyovenda et al., 2016).

After the concentration of the fine particulates was determined, the filter papers were put in desiccators and later removed for digestion. They were digested with concentrated nitric acid and hydrofluoric acid and placed in fume cardboard at a temperature of 150. After the digestion, it was filtered through Whatman filter paper number 42 , and the filtrates were collected, with some amount of distilled water added to it to form a standard volume of $100 \mathrm{ml}$. A blank was also prepared in the same way. The filtrates were tested for the concentration of eight heavy metals ( $\mathrm{Ni}, \mathrm{Co}, \mathrm{Cu}, \mathrm{Pb}, \mathrm{Cd}, \mathrm{Cr}, \mathrm{Mn}$, and $\mathrm{Zn}$ ) using Atomic Absorption Spectrophotometer (Serial No. AA0904M046) Flame Test following the user manual from the Multi-User Scientific Research Laboratory of the Ahmadu Bello University, Zaria (MUSRL/ABU Zaria). Since many people live and work close to these industrial sites, there is the possibility of potential health effects, Thus toxicity potential (TP) was determined from Equation (2).

$$
\mathrm{TP}=\frac{\text { Measured concentration of } \mathrm{PM}_{2.5 \& 10} / \text { Heavy metals }\left(M_{i}\right)}{\text { Permissible limit set by WHO } / \mathrm{EU}}
$$

where $M_{i}$ is the $i^{\text {th }}$ metal (Ediagbonya et al., 2013).

\subsection{Study Area}

The study area covers three industrial sites that were carefully selected from the cities of Kano, Kaduna, and Jos all in Northern Nigeria. The area is approximately $921 \mathrm{~km}^{2}$ and is located within latitude $(9.89$ - 12.002) $\mathrm{N}$ and longitude (7.41 - 8.858) E. The estimated population of the area is 6,024,994 according to world population review (PCN, 2020). The climate of the area is characterized by the wet and dry season. The rainy season set in between April and October while the dry season is between November and March (Abdulkadir et al., 2015). Prominent anthropogenic activities that release fine particulates and heavy metal pollution in the ambient air of these industrial sites are vehicular emissions, burning of fossil fuel, emission from the exhaust of power plant, emission from industrial fork lifters' exhaust, emissions from stacks, and resuspended dust.

The sites are selected in the study towns based on accessibility for monitoring and population density around them. The sites are summarized in Table 1, and Figure 1 is the geographical map of northern Nigeria showing their locations. 
Table 1. Monitoring sites, location/cities, and elevation across northern Nigeria.

\begin{tabular}{|c|c|c|c|c|}
\hline \multirow{2}{*}{ S/N Sites/ (Site code) } & \multirow{2}{*}{ Location/City } & \multicolumn{2}{|c|}{ Coordinates } & \multirow{2}{*}{ Elevation (m) } \\
\hline & & Lat. (N) & Long. (E) & \\
\hline 1. Terytex Nig. Ltd./(i) & $\begin{array}{c}\text { Airport road/Independence } \\
\text { Road, Kano }\end{array}$ & $12^{\circ} 01^{\prime} 19.7^{\prime \prime}$ & $08^{\circ} 32^{\prime} 73.1^{\prime \prime}$ & 486.9 .00 \\
\hline 2. Jhako Tech. Ltd./(j) & $\begin{array}{l}2 \text { Moh'd Ladan Road, } \\
\text { Kakuri, Kaduna }\end{array}$ & $10^{\circ} 27^{\prime} 11.4^{\prime \prime}$ & $07^{\circ} 27^{\prime} 11.4^{\prime \prime}$ & 612.10 \\
\hline 3. Grand Cereals Ltd./(k) & Zawan Junction, Jos & $09^{\circ} 45^{\prime} 37.0^{\prime \prime}$ & $08^{\circ} 51^{\prime} 24.3^{\prime \prime}$ & 1214.00 \\
\hline
\end{tabular}

Where Lat. and Long. denote latitude and longitude respectively.

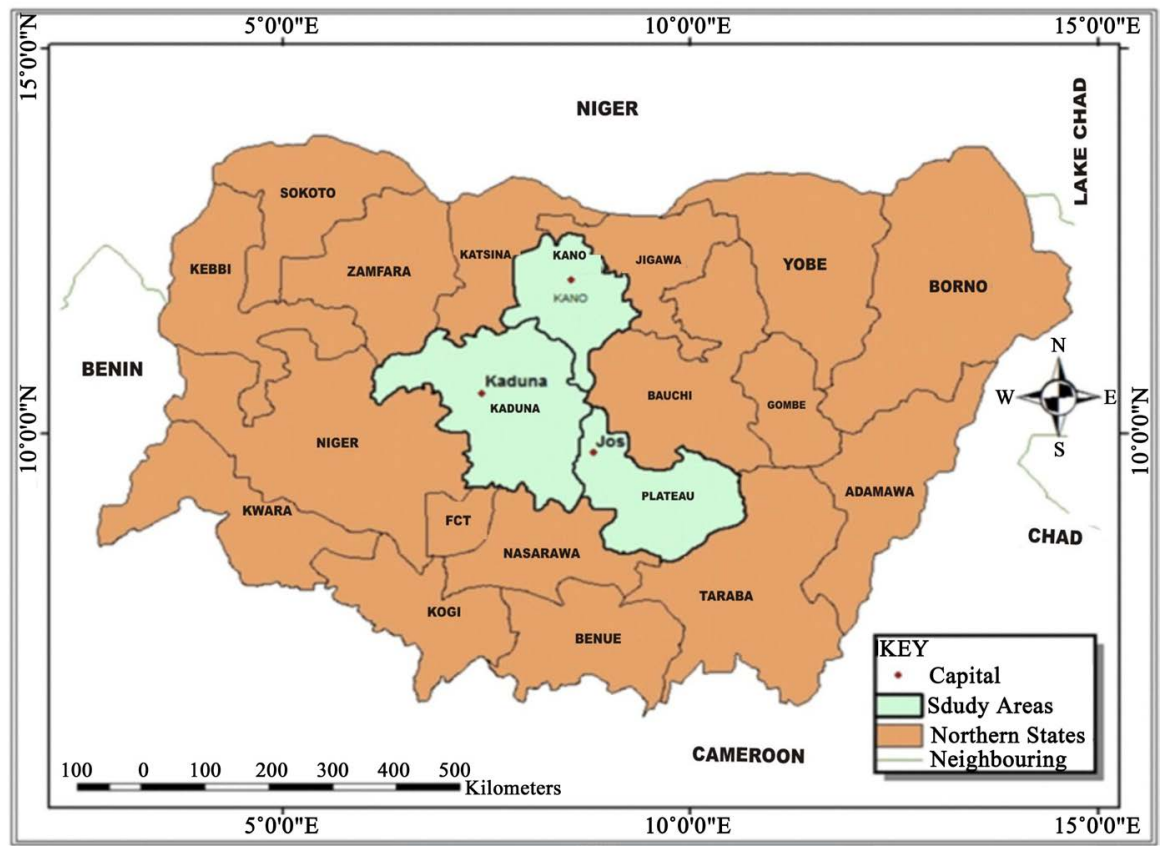

Figure 1. Map of northern Nigeria region showing the study areas.

\subsection{Correlation Analysis between the $\mathbf{P M}_{2.5}$ and $\mathbf{P M}_{10}$ Concentrations and Multiple Correlations of the Heavy Metals in the Industrial Sites}

To determine the relationships that exist between the $\mathrm{PM}_{2.5}$ and $\mathrm{PM}_{10}$ concentrations Pearson correlation Equation (3) was used.

$$
R=\frac{n \sum c \mathrm{PM}_{2.5} c \mathrm{PM}_{10}-\sum c \mathrm{PM}_{2.5} \sum c \mathrm{PM}_{10}}{\sqrt{\left[n \sum c \mathrm{PM}_{2.5}{ }^{2}-\sum c \mathrm{PM}_{2.5}{ }^{2}\right]} \sqrt{\left[n \sum c \mathrm{PM}_{10}{ }^{2}-\sum c \mathrm{PM}_{10}{ }^{2}\right]}}
$$

where $n$ is the number of data pairs, and $c$ is the concentrations (Ayua et al., 2017).

While Real Statistics Resource Pack Software (updated 6.8 version) Equations (4)-(6), as presented by Zaiontz (2020), were used for calculating the multiple correlations coefficient of the heavy metals concentrations in all the sites.

$$
R_{i, j k}=\sqrt{\frac{R_{i j}^{2}+R_{j k}^{2}-2 R_{i j} R_{j k} R_{i k}}{1-R_{j k}^{2}}}
$$




$$
\begin{aligned}
& R_{k, i j}=\sqrt{\frac{R_{i k}^{2}+R_{j k}^{2}-2 R_{i j} R_{j k} R_{i k}}{1-R_{i j}^{2}}} \\
& R_{j, i k}=\sqrt{\frac{R_{i j}^{2}+R_{j k}^{2}-2 R_{i j} R_{j k} R_{i k}}{1-R_{i k}^{2}}}
\end{aligned}
$$

where $R_{i, j k}$ means concentrations of metals in site $i$ are dependent on those of sites $j$ and $k, R_{i j}^{2}$ is the coefficient of determination and $R_{i j}$ denotes the correlation of metals in any two given sites (Zaiontz, 2020).

\section{Results and Discussion}

The results of the monthly mean particulates matter $\left(\mathrm{PM}_{2.5}\right.$ and $\left.\mathrm{PM}_{10}\right)$ measured from the industrial sites between September 2018-August 2019 is computed together with the toxicity potential using Equations ((1), (2)) from all the sites and presented in Table 2, we used the World Health Organization (WHO) permissible limit of $25.0 \mu \mathrm{g} \cdot \mathrm{m}^{-3}$ and $50.0 \mu \mathrm{g} \cdot \mathrm{m}^{-3}$ for $\mathrm{PM}_{2.5}$ and $\mathrm{PM}_{10}$ respectively. While the results of the heavy metals concentrations were given in part per million (ppm) by AAS but were converted to $\mathrm{mg} \cdot \mathrm{m}^{-3}$ using Equation (7) and presented in Table 3 along with their respective toxicity potentials.

$$
1 \mathrm{mg} \cdot \mathrm{m}^{-3}=0.041 \mathrm{ppm} \times m_{i}
$$

where $m_{i}$ is the molecular weight of the metal $(i)$ in $\mathrm{g} \cdot \mathrm{mol}^{-1}$ and 0.041 is the conversion factor at standard temperature (Tyovenda et al., 2016).

As can be seen in Table 2 and Figures 2-4, the month of December and January

Table 2. Monthly mean concentrations of fine particulates $\left(\mathrm{PM}_{2.5}\right.$ and $\left.\mathrm{PM}_{10}\right)$ in $\mu \mathrm{g} \cdot \mathrm{m}^{-3}$ as measured in the industrial sites from September 2018-August 2019 with their toxicity potentials (TP).

\begin{tabular}{ccccccc}
\hline \multirow{2}{*}{ Month/year } & \multicolumn{5}{c}{ Industrial Sites } \\
\cline { 2 - 7 } & Terytex Nig. Ltd., Kano & Jhako Tech. Ltd., Kaduna & Grand Cereals Ltd., Jos \\
\hline & PM $_{2.5} / \mathrm{TP}$ & $\mathbf{P M}_{10} / \mathrm{TP}$ & $\mathbf{P M}_{2.5} / \mathrm{TP}$ & $\mathbf{P M}_{10} / \mathrm{TP}$ & PM$_{2.5} / \mathrm{TP}$ & PM $_{10} / \mathrm{TP}$ \\
Sept./2018 & $19.20 / 0.77$ & $46.78 / 0.94$ & $14.71 / 0.59$ & $36.70 / 0.73$ & $14.30 / 0.57$ & $30.60 / 0.61$ \\
Oct./2018 & $15.10 / 0.60$ & $36.08 / 0.72$ & $18.94 / 0.76$ & $47.78 / 0.96$ & $12.90 / 0.52$ & $26.80 / 0.54$ \\
Nov./2018 & $22.30 / 0.45$ & $48.00 / 0.96$ & $20.94 / 0.84$ & $49.78 / 1.00$ & $21.40 / 0.86$ & $45.20 / 0.90$ \\
Dec./2018 & $25.30 / 1.01$ & $57.00 / 1.14$ & $24.94 / 1.00$ & $59.89 / 1.20$ & $45.11 / 1.80$ & $82.00 / 1.64$ \\
Jan./2019 & $27.10 / 1.08$ & $54.00 / 1.08$ & $23.10 / 0.92$ & $72.00 / 1.44$ & $40.11 / 1.60$ & $88.00 / 1.76$ \\
Feb./2019 & $19.10 / 0.76$ & $44.00 / 0.88$ & $26.11 / 1.04$ & $62.00 / 1.24$ & $32.30 / 1.29$ & $52.60 / 1.05$ \\
Mar./2019 & $15.90 / 0.64$ & $33.70 / 0.67$ & $28.90 / 1.16$ & $58.70 / 1.17$ & $12.90 / 0.52$ & $22.80 / 0.46$ \\
Apr./2019 & $11.90 / 0.48$ & $46.89 / 0.94$ & $21.90 / 0.88$ & $48.70 / 0.97$ & $33.90 / 1.36$ & $52.80 / 1.06$ \\
May/2019 & $11.92 / 0.48$ & $22.72 / 0.45$ & $19.90 / 0.80$ & $58.69 / 1.17$ & $22.90 / 0.92$ & $40.20 / 0.80$ \\
Jun./2019 & $15.92 / 0.64$ & $33.70 / 0.67$ & $19.90 / 0.80$ & $48.69 / 0.97$ & $14.90 / 0.60$ & $39.80 / 0.80$ \\
Jul./2019 & $14.71 / 0.59$ & $32.70 / 0.65$ & $21.90 / 0.88$ & $48.70 / 0.97$ & $16.00 / 0.64$ & $39.60 / 0.79$ \\
Aug./2019 & $11.71 / 0.47$ & $22.70 / 0.45$ & $13.80 / 0.55$ & $30.69 / 0.61$ & $14.00 / 0.56$ & $29.60 / 0.59$ \\
\hline
\end{tabular}

Note: TP that are harmful to human are indicated with bold figures. 


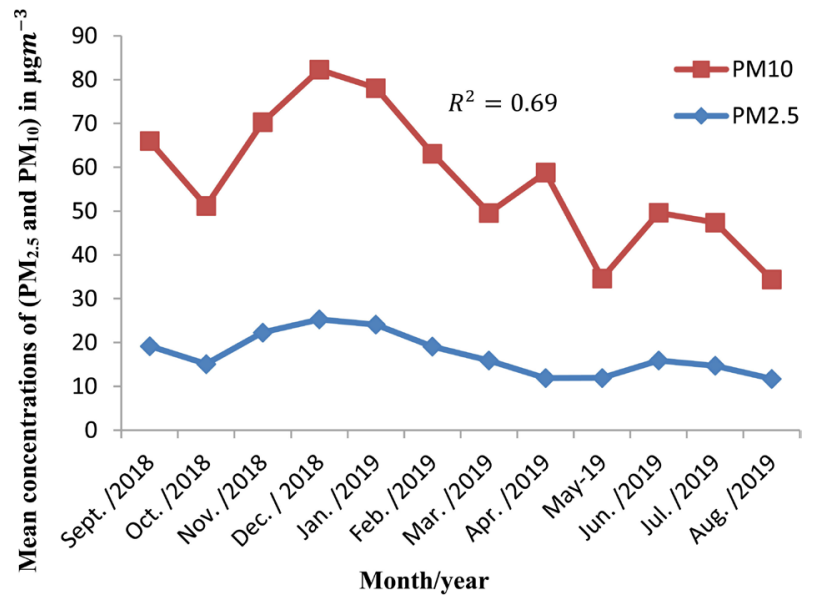

Figure 2. Variation of monthly mean concentrations of $\mathrm{PM}_{2.5}$ and $\mathrm{PM}_{10}$ in Terytex industry, Kano.

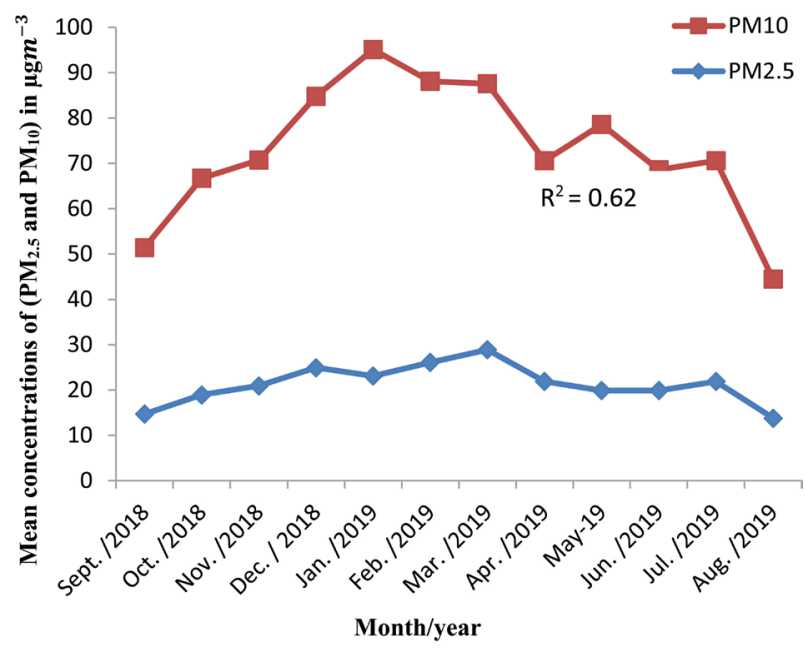

Figure 3. Variation of monthly mean concentrations of $\mathrm{PM}_{2.5}$ and $\mathrm{PM}_{10}$ in Jhako Tech., Kaduna.

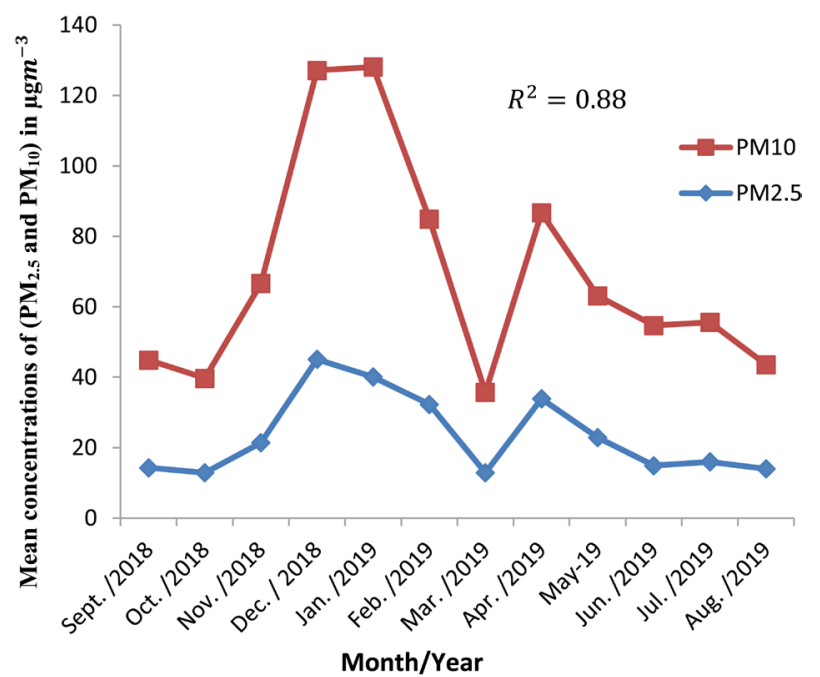

Figure 4. Variation of monthly mean concentrations of $\mathrm{PM}_{2.5}$ and $\mathrm{PM}_{10}$ in Grand Cereals, Jos. 
had the highest mean concentrations of $\mathrm{PM}_{2.5}$ and $\mathrm{PM}_{10}$ in the Grand Cereals industry, Jos with toxicity potentials in December, January, February, and April exceeding unity and thus posing potential threats to the lives of the people living and working in the site. In the Jhako industry, higher concentrations of $\mathrm{PM}_{2.5}$ were captured in March and February with TP values exceeding unity while $\mathrm{PM}_{10}$ had concentrations in December, January, February, March, and April more than the set standard of $50.0 \mu \mathrm{g} \cdot \mathrm{m}^{-3}$. However, in the Terytex industry, the results were promising as concentrations of $\mathrm{PM}_{2.5}$ and $\mathrm{PM}_{10}$ exceeded the set standard of $25.0 \mu \mathrm{g} \cdot \mathrm{m}^{-3}$ and $50.0 \mu \mathrm{g} \cdot \mathrm{m}^{-3}$ in December and January only. Higher concentrations $\mathrm{PM}_{2.5}$ and $\mathrm{PM}_{10}$ with toxicity potentials exceeding one occurred consistently in almost all the three sites in December 2018-April 2019. The reason for this may not be farfetched from the fact that within these periods of the study, the rain was reduced, washout was also reduced and resuspension of dust was enhanced by the harmattan. On average the receptors of the Grand Cereals industry, Jos are more susceptible to respiratory infections like asthma, chronic bronchitis, benign, airways irritation, coughing or difficulty breathing, and aggravation of tuberculosis/COVID-19 symptoms (Lopez et al., 2005; WHO, 2020).

The correlations between the $\mathrm{PM}_{2.5}$ and $\mathrm{PM}_{10}$ concentrations in the industrial site determine using equation 3 were positive and very strong with $\mathrm{R}$ ranging from 0.7 - 0.9. This means that these particulates originate from similar anthropogenic sources from the industrial vicinities. The correlation was stronger at the Grand Cereals industry, Jos with the coefficient of determination $\mathrm{R}^{2}=0.88$, followed by the Terytex industry, Kano with $\mathrm{R}^{2}=0.69$.

The results of Table 3 and Figure 5 showed that of the eight heavy metals $(\mathrm{Ni}$, $\mathrm{Co}, \mathrm{Cu}, \mathrm{Pb}, \mathrm{Cd}, \mathrm{Cr}, \mathrm{Mn}$, and $\mathrm{Zn}$ ) analyzed in all the sites only Nickel, Lead and Cadmium that had values in the ambient air exceeding the set standard by WHO/EU in Terytex industry, Kano and Grand Cereals, Jos. The shaded area of Figure 5 and Table 3 showed that the Concentration Ni was highest in the Terytex industry followed by Grand Cereals, Jhako has the highest concentrations of copper, followed by Grand cereals with Grand Cereals recording higher concentrations of $\mathrm{Pb}, \mathrm{Cd}, \mathrm{Cr}, \mathrm{Mn}$, and Zinc. Diseases like diarrhea, gastrointestinal disorders, tremor, stomatitis, hemoglobinuria, paralysis, ataxia, vomiting and convulsion, depression, and pneumonia may be prevalent within these industrial areas (Taghipour et al., 2013). Other effects of inhaling heavy metals in the air like neurotoxic, or even carcinogenic, mutagenic, or teratogenic may also occur (Singh et al., 2010). For example, workers that inhale excessive $\mathrm{Pb}$ were reported by Lin et al. (2016) to suffer damages of the nervous, skeletal, endocrine, enzymatic, circulatory, and immune system. While chronic effects of inhaling Cd include lung cancer, kidney dysfunction, hypertension, pulmonary adenocarcinomas, prostatic proliferative lesions, and bone fractures (Brevik et al., 2015; Kamani et al., 2014; Mafuyai et al., 2014). Exposure to enhanced levels of Nickel may results in $\mathrm{Ni}$ dermatitis consisting of itching of the fingers, hands, and forearms also Lu et al. (2010) reported that exposure high levels of nickel compounds cause 
Table 3. Mean concentration of heavy metals $\left(\mathrm{mg} \mathrm{m}^{-3}\right)$ in the industrial sites with their toxicity potentials (TP).

\begin{tabular}{ccccc}
\hline \multirow{2}{*}{ Metals $\left(\mathrm{M}_{\mathrm{i}}\right) / \mathrm{TP} P$} & $\begin{array}{c}\text { Industrial Sites } \\
\text { Jhako Tech. Ltd., } \\
\text { Kaduna }\end{array}$ & $\begin{array}{c}\text { Terytex, Nig. } \\
\text { Ltd., Kano }\end{array}$ & $\begin{array}{c}\text { Grand cereals } \\
\text { Ltd., Jos }\end{array}$ & $\begin{array}{c}\text { Permissible limit } \\
\text { Set by WHO/EU } \\
\left(\mathrm{mg} \cdot \mathbf{m}^{-3}\right)\end{array}$ \\
\hline Nickel & $0.046 / 0.92$ & $0.058 / 1.16^{*}$ & $0.064 / 1.28^{*}$ & 0.050 \\
Cobalt & $0.000 / 0.00$ & $0.000 / 0.00$ & $0.000 / 0.00$ & 0.001 \\
Copper & $0.821 / 0.82$ & $0.086 / 0.09$ & $0.091 / 0.09$ & 1.000 \\
Lead & $0.014 / 0.28$ & $0.060 / 1.20^{*}$ & $0.090 / 1.80^{*}$ & 0.050 \\
Cadmium & $0.003 / 0.60$ & $0.009 / 1.80^{*}$ & $0.021 / 4.20^{*}$ & 0.005 \\
Chromium & $0.024 / 0.05$ & $0.045 / 0.09$ & $0.044 / 0.09$ & 0.500 \\
Manganese & $0.120 / 0.80$ & $0.144 / 0.96$ & $0.148 / 0.99$ & 0.150 \\
Zinc & $0.532 / 0.11$ & $4.967 / 0.99$ & $3.864 / 0.77$ & 5.000 \\
\hline
\end{tabular}

Note: Numbers bolded with * indicates toxicity potential that are harmful to human.

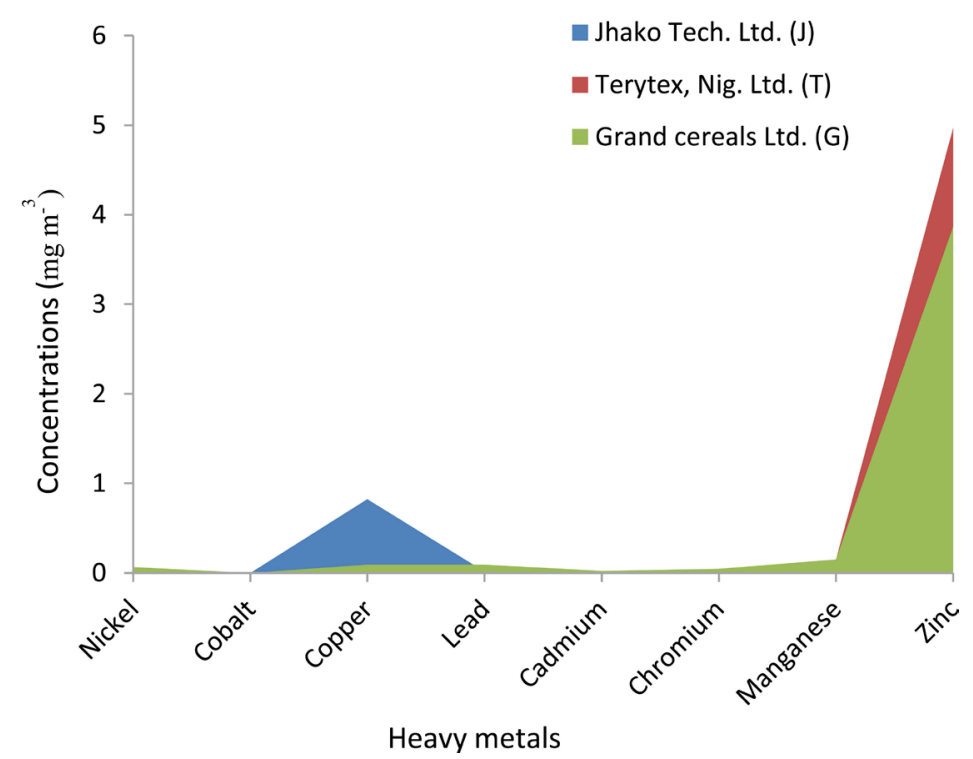

Figure 5. Variation of heavy metals concentrations in ambient air in the industrial sites.

intestinal disorders, convulsions, and asphyxia. Repeated exposure can cause sleeplessness, headache, dizziness, weakness, poor memory, tightness in the chest, loss of hair, loss of libido. Lung and nasal cancers have also been reported from exposure to nickel refinery dust and nickel sub sulfide (US Environmental Protection Agency, 1999).

It is surprising to observe that, the fine particulates concentration result was very promising in the Terytex industry, Kano while that of the heavy metals turn out to be the reverse since the heavy metals content was determined from these particles. These results suggested that inhaling Fine particulates matter can be potentially lethal even at concentrations below the regulatory limits.

From the results of a two-way correlation analysis carried out on the heavy metals concentrations in the three sites using Equations (4)-(6), it was found that the highest correlation $\mathrm{R}=0.99$ was observed for site $i, k$ with site $j, i$ and $j$, 
$k$ recording $\mathrm{R}=0.45$ each respectively. The multiple results as tested by Equations (4)-(6) gives a strong correlation with $\mathrm{R}=0.83$ in all the cases respectively. These strong correlations indicate the interdependence of these metal pairs and could be attributed to the presence of these metals in similar sources (i.e. industrial operations, the exhaust of power plants, emissions from folk lifters, emission stacks, and dust generated from the processing of industrial raw materials as well as vehicular emissions).

\section{Conclusion}

The concentration levels of fine particulates $\left(\mathrm{PM}_{2.5}\right.$ and $\left.\mathrm{PM}_{10}\right)$ and eight heavy metals $(\mathrm{Ni}, \mathrm{Co}, \mathrm{Cu}, \mathrm{Pb}, \mathrm{Cd}, \mathrm{Cr}, \mathrm{Mn}$, and $\mathrm{Zn}$ ) and their toxicity levels in ambient air collected from three industrial sites in northern Nigeria has been examined in this study. The monthly mean concentrations levels of $\left(\mathrm{PM}_{2.5}\right.$ and $\left.\mathrm{PM}_{10}\right)$ captured during the dry season months of December, January, February, and April in Grand Cereals industry, Jos and Jhako Technology, Kaduna exceeded the regulatory limit value of 25.0 $\mu \mathrm{g} \cdot \mathrm{m}^{-3}$ and $50.0 \mu \mathrm{g} \cdot \mathrm{m}^{-3}$ as set by $\mathrm{WHO}$ for $\mathrm{PM}_{2.5}$ and $\mathrm{PM}_{10}$ respectively.

However, in the Terytex industry, the results were promising as concentrations of $\mathrm{PM}_{2.5}$ and $\mathrm{PM}_{10}$ exceeded the set standard of $25.0 \mu \mathrm{g} \cdot \mathrm{m}^{-3}$ and $50.0 \mu \mathrm{g} \cdot \mathrm{m}^{-3}$ in December and January only. Higher concentrations $\mathrm{PM}_{2.5}$ and $\mathrm{PM}_{10}$ with toxicity potentials exceeding one occurred consistently in almost all the three sites in December 2018-April 2019. The reason for this is because, during these periods of the study, the rain was reduced, washout was also reduced and resuspension of dust was enhanced by the harmattan. The correlation between the $\mathrm{PM}_{2.5}$ and $\mathrm{PM}_{10}$ concentrations in the industrial site was positive and very strong with $\mathrm{R}$ ranging from 0.7 - 0.9. This means that these particulates originate from similar anthropogenic sources from the industrial vicinities.

The study also reported varying concentrations of the eight heavy metals $(\mathrm{Ni}$, $\mathrm{Co}, \mathrm{Cu}, \mathrm{Pb}, \mathrm{Cd}, \mathrm{Cr}, \mathrm{Mn}$, and $\mathrm{Zn}$ ) analyzed in all the sites with only Nickel, Lead, and Cadmium concentrations in the ambient air exceeding the set standard by WHO/EU in Terytex industry, Kano and Grand Cereals, Jos. At all the industrial areas sampled, cadmium recorded the highest toxicity potential of 4.20 , in the Grand Cereals industry, Jos while Co concentrations were below detection levels by AAS in all the sites studied. The inter-elemental multiple correlation coefficients of the heavy metals in the three sites revealed a very strong correlation $(\mathrm{R}>0.8)$ and high positive correlation were observed for any of the two pairs with $\mathrm{R}$ ranging from 0.5 to 1.0. These means common sources of anthropogenic inputs contributed to the heavy metals recorded from the industrial areas. We suggested that for cleaner air quality, these industries install electrostatic precipitators to combat fine particulates emission from their stack and also recommended a proper legislative framework to regulate and control industrial fugitive emissions to protect northern Nigeria air shed.

\section{Acknowledgements}

We appreciate the cooperation and kindness of Eng. Aondowase Kwaza, the 
Manager of Jhako Technologies, Kaduna, Eng. David Dafeng of Grand Cereals, Jos, and Eng. Haruna Abubakar of Terytex industry, Kano for granting us access to carry out this study within their industrial premises.

\section{Conflicts of Interest}

The authors declare no conflicts of interest regarding the publication of this paper.

\section{References}

Abah, J., Mashebe, P., \& Onjefu, S. A. (2020). Heavy Metals Pollution Status of the Katima Mulilo Urban Open Land Wastewater Disposal Centre and the Immediate Vicinity. Cogent Environmental Science, 6, Article ID: 1726093. https://doi.org/10.1080/23311843.2020.1726093

Abdulkadir, A., Usman, M. T., \& Shaba, A. H. (2015). An Integrated Approach to Dilineation of the Eco-Climatic Zones in Northern Nigeria. Journal of Ecology and the Natural Environment, 7, 247-255. https://doi.org/10.5897/JENE2015.0532

Akolkar, A. B., Suresh, S. S., Kumari, V. A., Sowmya, D., \& Karunagaran, K. (2015). Study of Impacts of Industrial Stack Emissions and DG Sets Emissions at Peenya Industrial Area Bengaluru Using Air Dispersion Model. Central Bengaluru: Pollution Control Board Zonal Office.

Anietie, O. V., \& Labunmi, L. (2015). Surface Soil Pollution by Heavy Metals: A Case Study of Two Refuse Dump-Sites in Akure Metropolis. International Journal of Scientific Research, 4, 71-74.

Ayua, T. J., Tyovenda, A. A., Igyuse, I. S., \& Ejegwoya, O. P. (2017). Determination of Ionizing Radiation Exposure Levels within Four Local Mining Sites Selected from Sardauna Local Government Area of Taraba State-Nigeria. International Journal of Physics, 5, 157-161. https://doi.org/10.12691/ijp-5-5-3

Brevik, E. C., Cerdà, A., Mataix-Solera, J., Pereg, L., Quinton, J. N., Six, J., \& Van Oost, K. (2015). The Interdisciplinary Nature of SOIL. SOIL, 1, 117-129. https://doi.org/10.5194/soil-1-117-2015

Carretero-Peña, S., Blázquez, L. C., \& Pinilla-Gil, E. (2019). Estimation of $\mathrm{PM}_{10}$ Levels and Sources in Air Quality Networks by Digital Analysis of Smartphone Camera Images Taken from Samples Deposited on Filters. Sensors, 19, 4791. https://doi.org/10.3390/s19214791

Dong, J., Yang, Q. W., Sun, L. N., Zeng, Q., Liu, S. J., \& Pan, J. (2011). Assessing the Concentration and Potential Dietary Risk of Heavy Metals in Vegetables at a $\mathrm{Pb} / \mathrm{Zn}$ Mine Site, China. Environmental Earth Sciences, 64, 1317-1321. https://doi.org/10.1007/s12665-011-0992-1

Ediagbonya, T. F., Ukpebor, E., Okiemien, F., \& Ogungbowa, G. (2013). Spatio-Temporal Distribution of Inhalable and Respirable Particulate Matter in Rural Atmosphere of Nigeria. Environmental Skeptics and Critics, 2, 20-29.

Hadlocon, L. S., Zhao, L. Y., Bohrer, G., Kenny, W., Garrity, S. R., Wang, J., Wyslouzil, B., \& Upadhyay, J. (2015). Modeling of Particulate Matter Dispersion from a Poultry Facility Using AERMOD. Journal of the Air \& Waste Management Association, 65, 206-217. https://doi.org/10.1080/10962247.2014.986306

Kamani, H., Hoseini, M., Safari, G. H., Jaafari, J., \& Mahvi, A. H. (2014). Study of Trace Elements in Wet Atmospheric Precipitation in Tehran, Iran. Environmental Monitoring and Assessment, 186, 5059-5067. https://doi.org/10.1007/s10661-014-3759-9 
Karagulian, F., Belis, C. A., Dora, C. F. C., Prüss-Ustün, A., Bonjour, S., Adair-Rohani, H., \& Amann, M. (2015). Contributions to Cities' Ambient Particulate Matter (PM): A Systematic Review of Local Source Contributions at Global Level. Atmospheric Environment, 120, 475-483. https://doi.org/10.1016/j.atmosenv.2015.08.087

Kasassi, A., Rakimbei, P., Karagiannidis, A., Zabaniotou, A., Tsiouvaras, K., Nastis, A., \& Tzafeiropoulou, K. (2008). Soil Contamination by Heavy Metals: Measurements from a Closed Unlined Landfill. Bioresource Technology, 99, 8578-8584.

https://doi.org/10.1016/j.biortech.2008.04.010

Lin, Y., Zhuang, L. Z., Ma, H., Wu, L. X., Huang, H. L., \& Guo, H. H. (2016). Study on Congenital Cardiac Anomalies Induced by Arsenic Exposure before and during Maternal Pregnancy in Fetal Rats. Journal of Hygiene Research, 45, 93-97.

Lopez, J. M., Callen, M. S., Murillo, R., Garcia, T., Narvarro, M. V., Cruz, M. T., \& Mastral, A. M. (2005). Levels of Selected Metals in Ambient Air PM10 in an Urban Site of Zaragoza (Spain). Environmental Research, 99, 58-67. https://doi.org/10.1016/j.envres.2005.01.007

Lu, X., Wang, L., Li, L., Lei, Y. K., Huang, L., \& Kang, D. (2010). Multivariate Statistical Analysis of Heavy Metals in Street Dust of Baoji, NW China. Journal of Hazardous Materials, 173, 744-749. https://doi.org/10.1016/j.jhazmat.2009.09.001

Mafuyai, G. M., Ishaq, S. E., \& Sha'Ato, R. (2014). Concentration of Heavy Metals in Respirable Dust in Jos Metropolitan Area, Nigeria. Open Journal of Air Pollution, 3, 10-19. https://doi.org/10.4236/ojap.2014.31002

Melaku, S., Morris, V., Raghavan, D., \& Hosten, C. (2008). Seasonal Variation of Heavy Metals in Ambient Air and Precipitation, at a Single Site in Washington, DC. Environmental Pollution, 155, 88-98. https://doi.org/10.1016/j.envpol.2007.10.038

Population of Cities in Nigeria (PCN) (2020). World Population Review. https://worldpopulationreview.com/countries/cities/nigeria

Shinggu, D. Y., Ogubuaja, V., Toma, O., \& Barminas, J. T. (2010). Determination of Heavy Pollutants in Street Dust of Yola, Adamawa State, Nigeria. African Journal of Pure and Applied Chemistry, 4, 17-20.

Singh, A., Sharma, R. K., Agrawal, M., \& Marshall, F. M. (2010). Health Risk Assessment of Heavy Metals via Dietary Intake of Foodstuffs from the Wastewater Irrigated Site of a Dry Tropical Area of India. Food and Chemical Toxicology, 48, 611-619. https://doi.org/10.1016/j.fct.2009.11.041

Taghipour, H., Mosaferi, M., Armanfar, F., \& Gaemmagami, S. J. (2013). Heavy Metals Pollution in the Soils of Suburban Areas in Big Cities: A Case Study. International Journal of Environmental Science and Technology, 10, 243-250. https://doi.org/10.1007/s13762-012-0143-6

Tyovenda, A. A., Ayua, T. J., \& Sombo, T. (2016). Heavy Metals Concentration Analysis in Air Particulates of Some Major Towns of Nasarawa State-Nigeria. International Research Journal of Environmental Sciences, 5, 22-28.

US Environmental Protection Agency (1999). Integrated Risk Information System (IRIS) on Nickel Refinery Dust. Washington DC: National Center for Environmental Assessment, Office of Research and Development.

WHO (World Health Organization) (2016). Ambient Air: A Global Assessment of Exposure and Burden of Diseases. WHO Library Cataloguing. http://www.who.int/iris/bitstream/10665/250141/1/9789241511353-eng.pdf?ua=1

WHO (World Health Organization) (2020). Report of the WHO-China Joint Mission on Corona Virus Diseases 2019 (COVID-19).

Zaiontz, C. (2020). Real Statistics Using Excel. http://www.real-statistics.com/ 
Zeireini, F., Alt, F., Messerschmidt, J., Wiseman, C., Feldmann, I., Von Bohlen, A., Muller, J., Liebl, K., \& Puttmann, W. (2005). Concentration and Distribution of Heavy Metals in Urban Airborne Particulate Matter in Frankfurt am Main, Germany. Environmental Science and Technology, 39, 2983-2989. https://doi.org/10.1021/es040040t

Zhang, M.-K., Liu, Z.-Y., \& Wang, H. (2010). Use of Single Extraction Methods to Predict Bioavailability of Heavy Metals in Polluted Soils to Rice. Communications in Soil Science and Plant Analysis, 41, 820-831. https://doi.org/10.1080/00103621003592341 